Jurnal Ekonomi dan Industri

e-ISSN: $2656-3169$

Volume 22, No.1, Januari-April 2021

p- ISSN: 0853-5248

\title{
PENGARUH KUALITAS LAYANAN, HARGA DAN PROMOSI TERHADAP KEPUASAN PELANGGAN FAMILY DENTAL CLINIC CABANG JATIWARINGIN
}

\author{
Dewi Refiyanti *) \\ *) Mahasiswa Program Studi Manajemen FE UNKRIS \\ Alamat: Kampus UNKRIS, Jatiwaringin Jakarta Timur
}

\begin{abstract}
The purpose of this study was to determine the effect of service quality, price and promotion on customer satisfaction at the Jatiwaringin Branch of Family Dental Clinic. This research is included in the category of causal associative research using a quantitative approach. The population in this study were customers of the Jatiwaringin Family Dental Clinic branch for one month, namely 250 customers. The sampling technique used in this study is a probability sampling technique. By using the Slovin formula obtained a sample of 70 respondents. The method of analysis used is simultaneously regression. The conclusion simultaneously service quality, price and promotion can contribute to customer satisfaction. it means that the better the quality of service, price and promotions provided, the customers will be satisfied to do dental care at the Jatiwaringin branch of Family Dental Clinic.
\end{abstract}

Keywords: Service quality, price, promotion and customer satisfaction

\section{PENDAHULUAN}

Sejak abad ke-21, perkembangan bisnis dibidang jasa telah meningkat sangat pesat serta mengalami metamorphosis yang berkesinambungan. Salah satu contoh perubahan tersebut yaitu dalam hal perubahan teknologi dan gaya hidup (life style), dimana hal ini tidak lepas dari pengaruh globalisasi yang kini terjadi. Saat ini, layanan jasa yang bersaing di dunia pemasaran semakin banyak dan beragam, salah satunya yaitu praktik dokter gigi. Jasa yang ditawarkan oleh klinik gigi Family Dental Clinic hampir serupa dengan yang ditawarkan oleh klinik gigi pesaing. Dengan kondisi yang seperti ini, pelanggan dapat melakukan perbandingan atas tawaran jasa dan memilih mana yang terbaik bagi mereka. Tingkat kepusan pelanggan sangat terkait dengan kualitas pelayanan, harga dan promosi yang ditawarkan.

Semakin bertambahnya permintaan pelanggan maka akan memajukan para pengusaha di bidang jasa praktik dokter gigi khususnya pada Family Dental Clinic untuk ikut bersaing menawarkan kelebihan-kelebihannya. Family Dental Clinic cabang Jatiwaringin berlokasikan di Jl. Jatiwaringin Raya No. 192, Pondok Gede. Praktik dokter gigi ini sudah berdiri sejak tahun 2011 dengan menyediakan berbagai macam perawatan gigi diantaranya yaitu pemasangan behel, scalling, bleaching dan masih banyak lainnya. Ini merupakan salah satu praktik dokter gigi yang menawarkan berbagai perawatan gigi dan memiliki cukup banyak pelanggan. Dalam hal ini dapat dikatakan bahwa dalam proses pemasarannya usaha ini telah memiliki nama dan kepercayaan dimata pelanggan terhadap pelayanan, harga dan promosi yang ditawarkan sehingga dengan pernyataan tersebut apakah semua pelanggan dapat menyatakan puas dan tertarik untuk menggunakan jasa praktik dokter gigi ini.

Family Dental Clinic merupakan badan usaha yang bergerak dibidang jasa khususnya praktik dokter gigi, dituntut untuk dapat memberikan pelayanan yang maksimal agar tetap unggul dalam persaingan jangka panjang. Pelayanan adalah elemen yang sangat penting untuk meningkatkan kepuasan pelanggan. Kualitas pelayanan adalah suatu bentuk penilaian 
pelanggan terhadap tingkat pelayanan yang diterima (perceived service) dan tingkat layanan yang diharapkan (expected service). Dampak postif dari pelayanan yang baik akan meningkatkan kepuasan dan kesetiaan terhadap pelanggan. Untuk dapat bersaing, bertahan hidup dan berkembang, maka perusahaan dituntut untuk mampu memenuhi kebutuhan dan keinginan pelanggan dengan memberikan pelayanan yang terbaik dan berkualitas, sehingga pelanggan merasa puas dan dihargai sehingga mereka senang dan bersedia untuk jadi pelanggan tetap.

Bagi sebagian pelanggan, layanan di Family Dental Clinic bisa dibilang baik, kerenanya satu minggu sebelum berkunjung untuk melakukan perawatan, pelanggan diingatkan terlebih dahulu melalui media sosial sehingga dapat mengingatkan pelanggan yang tadinya lupa menjadi tidak lupa. Selain itu, pelayanan lain yang diberikan oleh Family Dental Clinic yaitu ketika pelanggan sedang menunggu antrean disajikan pula cemilan dan soft drink agar pelanggan yang menunggu bisa menikmati apa yang diberikan oleh klinik tersebut.

Harga dianggap sebagai faktor yang mempengaruhi keputusan pembelian. Ketika memutuskan suatu pembelian, konsumen tentunya akan mencari tahu harga dan membeli produk yang harganya paling sesuai dengan kemampuan membelinya. Dalam strategi penetapan harga, harga merupakan salah satu elemen yang mempengaruhi aktivitas perusahaan dan menciptakan keunggulan kompetitif bagi perusahaan. Namun, ini sering bertentangan dengan kebijakan penetapan harga. Penetapan harga oleh perusahaan harus disamakan dengan keadaan lingkungan dan perubahan yang terjadi, terutama pada saat persaingan yang semakin ketat dan perkembangan permintaan terbatas.

Dalam lingkungan kompetitif saat ini, perusahaan perlu mencermati faktor harga karena besar kecilnya harga yang ditetapkan akan sangat mempengaruhi kemampuan perusahaan dalam bersaing dan juga mampu mempengaruhi konsumen untuk membeli produknya. Agar dapat bersaing di pasar, perusahaan dapat mempertimbangkan harga pesaing sebagai pedoman dalam menentukan harga jual produk mereka. Harga untuk melakukan perawatan gigi di Family Dental Clinic belum dapat dikatan murah walaupun setiap bulannya klinik tersebut memberikan potongan harga kepada pelanggan yang melakukan perawatan, karenanya masih ada klinik gigi lain di wilayah Jatiwaringin yang memberikan harga murah untuk melakukan perawatan gigi.

Promosi yang dilakukan oleh Family Dental Clinic adalah promosi melalui media sosial seperti instagram dan facebook. Dipromosi ini perusahaan terlebih dahulu meng upload gambar, harga, dan sarana apa saja yang didapat jika melakukan perawatan di Family Dental Clinic agar nantinya konsumen tahu dan pada akhirnya tertarik untuk melakukan perawatan di klinik tersebut.

Tujuan penelitian ini adalah untuk mengetahui pengaruh kualitas pelayanan, harga dan promosi terhadap kepuasan pelanggan pada Family Dental Clinic Cabang Jatiwaringin.

\section{LANDASAN TEORI}

\section{Kepuasan Pelanggan}

Menurut Kotler dan Keller (2016) kepuasan (satisfaction) adalah perasaan senang atau kecewa seseorang yang timbul karena membandingkan kinerja yang telah dipersepsikan produk (atau hasil) terhadap ekspektasi mereka. Gerson (2002), kepuasan pelanggan adalah persepsi pelanggan bahwa harapan telah terpenuhi atau terlampaui, jika pelanggan berharap barang tersebut akan berfungsi dengan baik, jika tidak pelanggan akan kecewa. Maka perusahaan harus menemukan cara untuk mengatasi masalah tersebut sehingga pelanggan bisa menjadi puas. Pelanggan yang puas akan melakukan bisnis lebih banyak dan lebih 
sering dengan suatu perusahaan, sehingga keuntungan perusahaan lebih besar. Dengan kata lain pengertian kepuasan pelanggan menurut Hasan (2008), adalah kepuasan yang berlanjut menjadi customer loyalty (loyalitas pelanggan) yang berujung pada peningkatan volume penjualan yang lebih besar, asset lebih produktif dan return on invesment yang lebih tinggi. Setyawan dan Susila (2004), kepuasan pelanggan merupakan evaluasi spesifik terhadap keseluruhan pelayanan yang diberikan pemberi jasa, sehingga kepuasan pelanggan hanya dapat dinilai berdasarkan pengalaman yang pernah dialami saat proses pemberian pelayanan.

Kepuasan pelanggan dalam bidang jasa adalah suatu elemen yang sangat penting dalam menentukan tumbuh kembang perusahan agar tetap eksis dalam menghadapi persaingaan. Seperti yang dikemukakan oleh Kotler (2005), kepuasan pelanggan merupakan perasaan senang atau kecewa seseorang yang muncul setelah membandingkan antara persepsi atau kesannya terhadap kinerja (hasil) suatu produk yang dihasilkan oleh perusahaan. Jika pelayanan yang diberikan memenuhi permintaan pelanggan, maka pelanggan akan merasa puas dan jika pelayanan berada di bawah tingkat yang tidak diharapkan, pelanggan akan merasa tidak puas. Pelanggan yang merasa puas dengan sendirinya akan menceritakan ke orang lain bahwa pelayanan diklinik tersebut sangatlah memuaskan dan atau sebaliknya.

Menurut Tjiptono (2010), kepuasan pelanggan memiliki beberapa manfaat, diantaranya: 1). Hubungan antara perusahan dan pelanggan menjadi harmonis. 2). Mendorong terciptanya loyalitas pelanggan. 3). Membentuk suatu rekomendasi informasi dari mulut ke mulut, yang sangat menguntungkan bagi peusahaan. 4). Reputasi perusahan menjadi baik di mata pelanggan. 5). Keuntungan yang diperoleh meningkat. Berdasarkan pendapat tersebut di atas dapat disimpulkan bahwa kepuasan pelanggan mempunyai manfaat yang sangat menguntungkan bagi suatu perusahaan dalam hal ini Family Dental Clinic.

Menurut Kotler (2005), ada lima faktor kunci untuk menentukan kepuasan pelanggan yang harus diperhatikan perusahaan, yaitu: 1). Kualitas produk; Pelanggan akan merasa puas bila hasil evaluasi mereka menunjukkan bahwa produk yang mereka gunakan berkualitas. 2). Kualitas pelayanan; Pelanggan akan merasa puas bila mereka mendapatkan pelayanan yang baik atau sesuai dengan yang diharapkan. 3). Emosional; Pelanggan akan merasa bangga dan mendapatkan keyakinan bahwa orang lain akan kagum dengannya bila menggunakan produk dan merk tertentu sehingga menimbulkan kepuasan yang lebih tinggi. Kepuasan yang diperoleh bukan karena kualitas dari produk tetapi nilai sosial atau selfesteem yang membuat pelanggan menjadi puas terhadap merk tertentu. 4). Harga; Produk yang mempunyai kulalitas yang sama tetapi menetapkan harga yang relatif murah akan memberikan nilai yang relatiF tingggi kepada pelanggannya sehingga menimbulkan kepuasan. 5). Biaya; Pelanggan yang tidak perlu mengeluarkan biaya tambahan atau tidak perlu membuang waktu untuk mendapatka suatu produk atau jasa cenderung puas terhadap produk atau jasa itu.

Menurut Tjiptono (2010) indikator-indikator dalam pembentukan kepuasan terdiri dari: 1). Kesesuaian harapan; Merupakan tingkat kesesuaian antara kinerja produk yang diharapkan dan dirasakan oleh pelanggan, yang meliputi: a). Produk yang didapat sesuai atau melebihi harapan. b). Pelayanan yang dilakukan karyawan sesuai atau melebihi harapan. c). Fasiliitas penunjang yang diperoleh sesuai atau melebihi harapan. 2). Minat berkunjung kembali; Merupakan kesediaan pelanggan untuk berkunjung kembali atau melakukan pembelian ulang terhadap produk terkait, yang meliputi: a). Berminat berkunjung kembali karena pelayanan yang diberikan karyawan sangat memuaskan. b). Berminat berkunjung kembali dengan alasan nilai dan kegunaan yang didapat sesudah mengonsumsi produk. c). Berminaat berkunjung kembali karena fasilitas penunjang memadai. 3). Kesediaan merekomendasikan; Merupakan kesediaan pelanggan untuk merekomendasikan produk 
yang telah dirasakannya kepada orang lain, yang meliputi: a). Menyarankan kerabat untuk membeli produk yang ditawarkan karena pelayanan yang diberikan memuaskan. b). Menyarankan kerabat untuk membeli produk yang ditawarkan karena fasilitas penunjang yang diberikan memadai. c). Menyarankan kerabat untuk membeli produk yang ditawarkan karena manfaat yang diperoleh setelah mengkonsumsi sebuah produk jasa.

\section{Kualitas Layanan}

Tjiptono (2010), mengemukakan bahwa kualitas merupakan suatu kondisi dinamis yang berhubungan dengan produk, jasa, manusia, proses, dan lingkungan yang memenuhi atau melebihi harapan. Menurut Kotler dan Keller (2016), kualitas pelayanan adalah keseluruhan fitur dan sifat produksi atau pelayanan yang berpengaruh pada kemampuannya untuk memuaskan kebutuhan yang dinyatakan atau tersirat. Tjiptono (2010), mendefinisikan kualitas pelayanan adalah upaya pemenuhan kebutuhan dan keinginan konsumen, serta ketepatan penyampaian untuk mengimbangi harapan konsumen. Kualitas pelayanan menurut Kotler (2005), merupakan model yang menggambarkan kondisi pelanggan dalam membentuk harapan akan layanan dari pengalaman masa lalu, promosi dari mulut ke mulut, dan iklan dengan membandingkan pelayanan yang mereka harapkan dengan apa yang mereka terima/rasakan. Menurut Payne (2010), mendefinisikan bahwa kualitas pelayanan sebagai kemampuan sebuah organisasi memberikan pelayanan untuk memenuhi atau melebihi harapan pelanggan.

Ariani (2009) menyederhanakan sepuluh dimensi diatas menjadi lima dimensi pokok yang dikenal dengan SERVQUAL (service quality) yang terdiri dari: 1). Bukti fisik, yaitu kemampuan suatu perusahaan dengan menunjukkan eksistensinya kepada pihak eksternal. Penampilan dan kemampuan sarana dan prasarana fisik perusahaan yang dapat diandalakan serta keadaan lingkungan sekitarnya merupakan salah cara perubahan jasa dalam menajikan kualitas layanan terhadap pelanggan. Diantaranya meliputi fasilitas fisik (gedung, buku, rak buku, meja dan kursi, dan sebagainya), teknologi (peralatan dan perlengkapan yang digunakan), serta penampilan pegawai. 2). Keandalan adalah kemampuan perusahaan memberikan pelayanan sesuai dengan apa yang dijanjikan secara akurat dan terpercaya. Kinerja harus sesuai dengan harapan pelanggan yang tercermin dari ketepatan aktual, pelayanan yang sama untuk semua pelanggan tanpa kesalahan, sikap simpatik dan akurasi yang tinggi. 3). Daya tanggap adalah kemauan untuk membantu pelanggan dan memberikan jasa dengan cepat dan tepat dengan penyampaian informasi yang jelas. Mengabaikan dan membiarkan pelanggan menunggu tanpa alasan yang jelas menyebabkan persepsi yang negative dalam kualitas pelayanan. 4). Jaminan adalah pengetahuan, kesopan-santunan dan kemampuan para pegawai perusahaan untuk menumbuhkan rasa percaya para pelanggan kepada perusahaan. Hal ini meliputi beberapa komponen, antara lain: a). Komuikasi, yaitu secara terus menerus memberikan informasi kepada pelanggan dalam bahasa dan penggunaan kata yang jelas sehingga para pelanggan dapat denggan mudah mengerti apa yang diinformasikan pegawai serta dengan cepat dan tanggap menyikapi keluhan dan komplain dari para pelanggan. b). Kredibilitas, perlunya jaminan atas suatu kepercayaan yang diberikan kepada pelanggan, believability atau sifat kejujuran, menanamkan kepercayaan, memberikan kredibilitas yang baik bagi perusahaan pada masa yang akan datang. c). Keamanan, adanya suatu kepercayaan yang tinggi dari pelangggan akan pelayanan yang diterima. Tentunya pelayanan yang diberikan mampu memberikan suatu jaminan kepercayan. 5). Empati, yaitu memberikan perhatian yang tulus dan bersifat individual atau pribadi yang diberikan kepada pelanggan dengan berupaya memahami keinginan konsumen dimana suatu perusahaan diharapkan memiliki suatu pengertian dan 
pengetahuan tentang pelanggan, memahami kebutuhan pelanggan secara spesifik, serta memiliki waktu pengoperasian yang nyaman bagi pelanggan.

Menurut Wolkis, dikutip dalam Saleh (2002) terdapat enam prinsip kualitas layanan tersebut terdiri atas : 1). Kepemimpinan; Manajemen puncak harus memimpin dan mengarahkan organisasinya dalam upaya peningkatan kinerja kualitas. 2). Pendidikan; Semua karyawan perusahaan, mulai dari manajer puncak sampai karyawan operasional, wajib mendapatkan penekanan dalam pendidikan tersebut antara lain konsep dan strategi kualitas. 3). Perencanaan Strategik; Proses perencanaan strategi harus mencakup pengukuran dan tujuan kualitas yang digunakan dalam mengarahkan perusahaan untuk mencapai visi dan misinya. 4). Review; Proses review merupakan satu-satunya alat yang paling efektif bagi manajemen untuk mengubah perilaku organisasi. 5). Komunikasi' Implementasi strategi kualitas dan organissai dipengaruhi oleh proses komunikasi organisasi, baik dengan karyawan, pelanggan, maupun dengan stakeholder lainnya. 6). Total Human Reward; Reward dan recognition merupakan aspek krusial dalam implementasi strategi kualitas. Setiap karyawan berprestasi perlu diberi imbalan dan prestasinya harus diakui

\section{Harga}

Harga menurut Kotler dan Armstrong (2012) adalah sejumlah uang yang dibebankan atas suatu produk atau jasa, atau jumlah dari nilai yang ditukar konsumen atas manfaatmanfaat karena memiliki atau menggunakan produk atau jasa tersebut. Sedangkan menurut Tjiptono (2010), harga dapat diartikan sebagai komponen yang sangat penting bagi kelangsungan suatu organisasi karena harga berpengaruh langsung terhadap pendapatan perusahaan. Teori lain yang membahas tentang harga adalah Swastha (2010), harga adalah jumlah uang (ditambah beberapa produk kalau mungkin) yang dibutuhkan untuk mendapatkan sejumlah kombinasi dari barang beserta pelayanannya. Harga adalah sejumlah uang sebagai alat tukar untuk memperoleh produk atau jasa, Saladin (2003).

Penetapan harga perusahaan dapat menciptakan hasil penerimaan penjualan dari produk yang dihasilkan dan dipasarkannya. Peranan harga sangat penting terutama untuk menjaga dan meningkatkan posisi perusahaan di pasar yang tercermin dalam pangsa pasar perusahaan, disamping itu juga untuk meningkatkan penjualan dan keuntungan perusahaan. Dengan kata lain, penetapan harga mempengaruhi kemampuan bersaing perusahaan dan kemampuan perusahaan konsumen.

Menentukan kebijakan penetapan harga menurut Kotler (2005), diantaranya adalah: 1). Memilih tujuan penetapan harga. 2). Menentukan pemintaan. 3). Memikirkan biaya. 4). Menganalisis biaya, harga dan tawaran pesaing. 5). Memilih metode penetapan harga. 5). Memilih harga akhir

Menurut Wiyadi (2011), tingkat harga yang terjadi dipengaruhi oleh beberapa faktor sebagai berikut, yaitu: 1). Keadaan perekonomian; yang terjadi dimana harga berada pada satu tingkat yang rendah mengakibatkan pembeli akan berbondong-bondong untuk membeli. 2). Persaingan; harga jual barang sering dipengaruhi oleh keadaan persaingan yang ada. Dalam persaingan, penjual yang berjumlah banyak aktif menghadapi pembeli yang banyak pula. 3). Pengawasan pemerintah; dapat berupa harga minimum dan maksimum dan peraturan lainnya yang dapat mencegah usaha kearah monopoli. 4). Harga pesaing; perusahaan yang beroperasi dalam lingkungan pesaing harus mempertimbangkan kemungkinan reaksi atau pengaruh dari perushaan lain bila merubah harga. 5). Penetapan harga atas penawaran pesaing; penetapan harga yang digunakan untuk pendirian industry dan pengadaan oleh agen-agen pemerintah. 6). Regulasi harga oleh pemerintah; pemerintah ikut campur tangan dalam membatasi harga, hal ini disebabkan untuk menjaga agar laju 
inflasi tetap dalam batas-batas yang wajar. 7). Harga dan inflasi; harga cenderung meningkat. Biasanya perusahaan secara berkala juga akan menaikkan harga jualnya dengan tujuan untuk mengantisipasi laju inflasi selanjutnya. 8). Harga flexibel; strategi ini biasanya digunakan oleh perusahaan yang igin memperluas market sharenya dan dalam menghadapi peran yang dijalankan oleh pesaing.

Tujuan penetapan harga menurut Lupiyoadi (2013), mengemukakan bahwa: 1). Survival; merupakan usaha untuk tidak melaksanakan tindakan-tindakan untuk meningkatkan profit ketika perusahaan sedang dalam kondisi pasar yang tidak menguntungkan. Usaha tersebut cenderung untuk bertahan. 2). Profit Maximization; penentuan harga bertujuan untuk memaksimumkan profit dalam periode tertentu. 3). Sales Maximization; penentuan harga bertujuan untuk membangun pangsa pasar (market share) dengan melakukan penjualan pada awal yang merugikan. 4). Prestige; tujuan penentuan harga disini adalah untuk memposisikan jasa perusahaan tersebut sebagai jasa yang ekslusif. 5). ROI; tujuan penentuan tujuan harga didasarkan atas pencapaian return on investment yang diinginkan (ROI).

Menurut Kotler dan Amstrong (2012) indikator-indikator harga terdiri dari tiga bagian yaitu, harga jual, kesesuaian harga dan perbandingan harga. 1). Harga jual adalah besarnya harga yang dibebankan kepada pembeli yang diperoleh dari biaya produksi dan laba yang diharapkan. 2). Kesesuaian harga adalah penetapan harga yang dilakukan oleh penjual yang sesuai dengan kualitas produk yang dapat diperoleh konsumen.

3). Perbandingan harga adalah suatu metode dimana harga untuk produk baru ditetapkan dengan membandingkan manfaat yang ditawarkan dalam kategori yang sama.

\section{Promosi}

Menurut Madura (2001), promosi adalah tindakan menginformasikan atau mengingatkan tentang spesifikasi produk atau merek. Sedangkan menurut Swastha dan Irawan (2008), promosi adalah arus informasi atau persuasi satu arah untuk mengarahkan seorang atau organisasi terhadap tindakan yang menciptakan pertukaran dalam pemasaran. Menurut Sukirno dan Poerwanto (2014), promosi merupakan suatu ungkapan dalam arti luas tentang kegiatan-kegiatan yang secara efektif dilakukan oleh perusahaan (penjual) untuk mendorong konsumen membeli produk atau jasa yang ditawarkan. Swastha (2010), promosi didefinisikan sebagai arus informasi atau persuasi satu arah yang dibuat untuk mengarahkan seseorang atau organisasi kepada tindakan yang menciptakan pertukaran dalam pemasaran. Menurut Kotler (2005), promosi merupakan proses komunikasi suatu perusahaan dengan pihak-pihak berkepentingan sekarang dan yang akan datang.

Menurut Alma (2006), promosi adalah sejenis komunikasi yang memberikan penjelasan dan meyakinkan calon konsumen mengenai barang dan jasa dengan tujuan untuk memperoleh perhatian, mendidik, mengingatkan dan meyakinkan calon konsumen. Menurut Kismono (2001), perusahaan harus menetapkan tujuan promosi untuk mencapai tujuan perusahaan secasra lebih luas. Program promosi dapat didasarkan pada satu atau lebih dari tujuan berikut: 1). Memberikan informasi, tujuan utama dari seluruh kegiatan promosi adalah untuk diberikan informasi kepada konsumen potensial mengenai produk yang ditawarkan, dimana konsumen dapat membelinya, dan berapa harga yang ditetapkan. Konsumen memerlukan informasi-informasi tersebut dalam pengambilan keputusan pembelinya. 2). Meningkatkan penjualan, kegiatan promosi juga merupakan salah satu cara untuk meningkatkan penjualan. Perancang dapat merancang promosi penjualan dengan memberikan kupon belanja, sampel produk, dan banyak lagi. Untuk membujuk konsumen mencoba produk yang ditawarkan dengan harga yang lebih murah atau dengan tambahan keuntungan yang lain. 3). Untuk menstabilkan penjualan, perusahaan perlu melakukan 
kegiatan promosi agar tingkat penjualan perusahaan tidak mengalami penurun secara signifikan. 4). Memposisikan produk, perusahaan harus menempatkan produk dengan menekankan keunggulan produk mereka daripada produk pesaing. Strategi promosi yang tepat seperti iklan yang dapat membantu perusahaan. 5). Membentuk citra produk, upaya promosi yang dilakukan perusahaan dapat membantu image konsumen terhadap produk yang ditawarkan. Perusahaan dapat menggunakan media promosi untuk membangun citra produknya dimata konsumen.

Menurut Madura (2001) bahwa promotion mix adalah kombinasi cara yang baik dari varibel-varibel periklanan, Penjualan Personal, dan alat promosi yang lain, yang seluruhnya dirancang untuk mencapai tujuuan program penjualan. Dalam bauran promosi terdapat lima komponen dan dijabarkan sebagai berikut: 1). Periklanan; Yaitu suatu bentuk dari komunikasi impersonal yang digunakan oleh perusahaan untuk membangun kesadaran terhadap keberadaan jasa yang ditawarkan, menambah pengetahuan konsumen akan jasa yang ditawarkan serta membedakan diri perusahaan dengan para kompetitornya. 2). Penjualan Personal; Yaitu suatu bentuk interaksi langsung dengan satu calon pembeli atau lebih untuk melakukan persentasi, menjawab pertanyaan, dan menerima pesan dari pembeli maupun calon pembeli. Penjualan personal mempunyai peranan yang penting dalam pemasaran jasa, karena memiliki kekuatan yang unik yaitu wiraniaga dapat mengumpulkan pengetahuan tentang konsumen dan mendapatkan umpan balik dari konsumen. Namun penjualan personal membutuhkan biaya yang lebih besar daripada periklanan, kemungkinan dua kali lipat besarnya walaupun kegunaannya hampir sama dengan periklanan yang meliputi pembentukan kesadaran terhadap produk, penyampaian informasi, dan melakukan persuasi agar orang melakukan pembelian. 3). Promosi Penjualan; Promosi penjualan adalah kegiatan promosi selain periklanan, penjualan perorangan maupun publisitas, yang bersifat jangka pendek dan tidak dilakukan secara berulang serta tidak rutin, yang ditujukan untuk mendorong penjualan, serta lebih mempercepat respon pasar yang ditargetkan. 4). Publisitas dan Hubungan Masyarakat; Merupakan stimulasi non personal terhadap permintaan barang, jasa, ide, dan sebagainya dengan berita komersial yang berarti dalam media masa dan tidak dibayar untuk mempromosikan dan melindungi citra perusahaan atau produk individualnya. Keuntungan publisitas dan hubungan masyarakat terletak pada efisiensi biaya karena perusahaan tidak membayar media masa sebagai sarana promosi tersebut. Namun publisitas yang bersifat negative dapat menimbulkan dampak buruk bagi perushaan. 5). Informasi dari Mulut Ke Mulut; Dalam hal promosi jasa, peranan orang sangat penting. Pelanggan dekat dengan penyampaian pesan. Dengan kata lain pelanggan tersebut akan berbicara kepada pelanggan lain yang berpotensial tentang pengalamannya dalam menerima jasa tersebut.

Menurut Kotler dan Keller (2016) indikator-indikator dari promosi penjualan adalah sebagai berikut: 1). Kualitas promosi adalah tolak ukur untuk mengetahui seberapa baik promosi yang dilakukan oleh suatu perusahaan, misalnya konten isi, desain yang menarik, posisi dan media yang digunakan, dan lain sebagainya. 2). Waktu promosi adalah seberapa lama atau tenggang waktu promosi yang dilakukan oleh perusahaan.

\section{METODE PENELITIAN}

Penelitian ini termasuk dalam kategori penelitian asosiatif kausal dengan menggunakan pendekatan kuantitatif. Populasi dalam penelitiani ini adalah pelanggan Family Dental Clinic cabang Jatiwaringin selama satu bulan yaitu 250 pelanggan. Teknik 
sampling yang digunakan dalam penelitian ini adalah teknik probability sampling yaitu simple random sampling. (Sugiyono, 2018). Menurut Umar (2008), mengemukakan bahwa ukuran sampel suatu populasi dapat menggunakan bermacam-macam cara, salah satunya adalah dengan menggunakan teknik Slovin. Dengan menggunakan teknik Slovin didapat sampel sebanyak 70 responden. Metode analisi yang digunakan dengan regresi berganda.

\section{HASIL PENELITIAN DAN PEMBAHASAN}

\section{Hasil Penelitian}

\section{Uji kelayakan data}

Kualitas data yang dihasilkan dari pengguna instrumen penelitian dievaluasi melalui uji validitas dan uji reliabilitas. Uji tersebut masing-masing untuk mengetahui akurasi data yang dikumpulkan dari pengguna instrumen. Data penelitian tidak bermanfaat apabila instrumen yang digunakan untuk mengumpulkan data penelitian tidak memiliki validitas dan reliabilitas yang tinggi.

Pengujian validitas ini dilakukan untuk menguji apakah tiap butir pernyataan telah mewakili indikator yang akan diteliti, persyaratan minimum untuk dapat dikatakan valid adalah $r=0,30$. (Sugiyono, 2018). Jadi, apabila korelasi antara butir-butir pernyataan dengan skor total kurang dari 0,30 , maka butiran dalam instrumen tersebut dapat dikatakan tidak valid. Uji validitas dilakukan dengan melihat korelasi antara skor masing-masing butir pernyataan dengan skor total. Berdasarkan perhitungan koefisien korelasi skor tiap butir pernyataan kualitas layanan dari 70 responden sebanyak 14 pernyataan, harga sebanyak 10 pernyataan, promosi sebanyak 6 pernyataan dan kepuasan pelanggan sebanyak 10pernyataan dengan hasil total skor r-hitung lebih besar dari r-tabel 0,300.

Pengujian reliabilitas diperlukan untuk menguji seberapa jauh hasil pengukuran yang dapat diandalkan secara konsisten. Pada tabel-1, hasil pengujian reliabilitas menunjukkan bahwa nilai Cronbach's Alpha semua variabel dalam penelitian ini lebih besar dari 0.6, sehingga penelitian ini dapat dianggap reliabel.

Tabel 1: Hasil Uji Reliabilitas

\begin{tabular}{lccc}
\hline \multicolumn{1}{c}{ Variabel } & $\begin{array}{c}\text { Cronbach } \\
\text { Alpha }\end{array}$ & $\begin{array}{c}\text { Nilai kritis } \\
(\boldsymbol{\alpha})=\mathbf{5 \%}\end{array}$ & Keterangan \\
\hline Kualitas Layanan & 0.908 & 0.600 & Reliabel \\
Harga & 0.866 & 0.600 & Reliabel \\
Promosi & 0.659 & 0.600 & Reliabel \\
Kepuasan Pelanggan & 0.860 & 0.600 & Reliabel \\
\hline
\end{tabular}

Sumber: Data Primer, diolah tahun 2018

Berdasarkan rekapitulasi hasil uji realibilitas, nilai Cronbach alpha dari variabel kualitas layanan, harga, promosi dan kepuasan pelanggan memiliki nilai > 0,60 sebagai syarat dengan demikian semua variabel tersebut dinyatakan realiabel.

\section{Analisis Regresi Linear Berganda}

\begin{tabular}{|c|c|}
\hline Variabel & Parameter \\
\hline
\end{tabular}




\begin{tabular}{lcccccc}
\hline & $\begin{array}{c}\text { Mult. } \\
\text { R }\end{array}$ & $\begin{array}{c}\text { R } \\
\text { Square }\end{array}$ & Konstanta & $\begin{array}{c}\text { Koefisien } \\
\text { Regresi }\end{array}$ & Sig. & $\boldsymbol{\alpha}$ \\
\hline Kualitas_Layanan & & & & 0,288 & 0,003 & \\
Harga & 0,569 & 0,324 & 1,164 & 1,097 & 0,003 & 0,05 \\
Promosi & & & & 0,641 & 0,006 & \\
\hline
\end{tabular}

\begin{tabular}{l}
\hline Pengujian Signifikan \\
\hline F hitung $>$ F tabel $=10,525>2,744$ \\
\hline Sumber: Data primer, diolah, 2018
\end{tabular}

Sumber: Data primer, diolah, 2018

Persamaan regresi $\mathrm{Y}=1,164+0,288 \mathrm{X}_{1}+1,097 \mathrm{X}_{2}+0,641 \mathrm{X}_{3}$

Berdasarkan tabel-2, nilai F-hitung lebih besar dari F-tabel $(10,525>2,744)$, maka Ho tolak, Ha terima, artinya ada pengaruh yang signifikan kualitas layanan, harga dan promosi terhadap kepuasan pelanggan pada Family Dental Clinic Cabang Jatiwaringin. Nilai koefisien determinasi $\left(\mathrm{R}^{2}\right)$ sebesar 0.324 , artinya kualitas layanan, harga dan promosi secara bersama-sama memberikan kontribusi sebesar 32,4\% kepada kepuasan pelanggan pada Family Dental Clinic Cabang Jatiwaringin, sedangkan sisanya sebesar 37,6\% disumbangkan oleh variabel lain yang tidak diteliti..

Kualitas layanan, harga dan promosi berpengaruh positif dan signifikan terhadap kepuasan pelanggan Family Dental Clinic Cabang Jatiwaringin pada tingkat nyata 99\%. Koefisien kualitas layanan bertanda positif sebesar 0,288 , artinya jika ada peningkatan kualitas layanan, maka kepuasan pelanggan akan meningkat atau sebaliknya dengan asumsi harga dan promosi tidak berubah. Koefisien harga bertanda positif sebesar 1,097, artinya jika ada kenaikan harga, maka kepuasan pelanggan akan tetap meningkat atau sebaliknya, dengan asumsi kualitas layanan dan promosi tidak berubah. Koefisien promosi bertanda positif sebesar 0,641 , artinya jika ada peningkatan promosi, maka kepuasan pelanggan akan meningkat atau sebaliknya dengan asumsi kualitas layanan dan harga tidak berubah. Dengan demikian, hasil penelitian ini sesuai dengan hipotesis.

\section{Pembahasan}

\section{Pengaruh Kualitas Layanan, Harga dan Promosi terhadap Kepuasan Pelanggan Family Dental Clinic Cabang Jatiwaringin}

Berdasarkan hasil penelitian menunjukkan bahwa kualitas layanan, harga dan promosi secara simultan berpengaruh positif dan signifikan terhadap kepuasan pelanggan Family Dental Cosmetic. Secara umum dapat diketahui bahwa kualitas layanan, harga dan promosi merupakan faktor yang penting dalam meningkatkan kepuasan pelanggan. Temuan hasil penelitian ini juga didukung oleh temuan hasil penelitian yang dilakukan oleh Gulla, et al, (2015), Haryanto (2013), Pujiningrum (2015), Cristo, Saerang, dan Worang (2017), dan Hutagulung, Saerang dan Tumbuan (2015) dimana hasil penelitian menyatakan bahwa secara simultan kualitas layanan, harga dan promosi berpengaruh pengaruh terhadap kepuasan pelanggan.

\section{KESIMPULAN DAN SARAN}

\section{Kesimpulan}

Berdasarkan hasil penelitian dapat disimpulkan bahwa kualitas layanan, harga dan promosi meningkatkan kepuasan pelanggan Family Dental Clinic,. artinya semakin baik 
kualitas layanan, harga serta promosi yang diberikatn maka pelanggan akan merasa puas untuk melakukan perawatan gigi di Family Dental Clinic cabang Jatiwaringin.

\section{Saran}

Berdasarkan hasil penelitian mengenai dampak kualitas layanan, harga dan promosi terhadap kepuasan pelanggan di Family Dental Clinic cabang Jatiwaringin, dapat disampaikan beberapa saran, yaitu sebagai berikut: 1). Untuk meningkatkan kepuasan pelanggan Family Dental Clinic harus memperbaiki kualitas layanan baik sebelum dan setelah pelanggan melakukan perawatan. Terutama yang berkaitan dengan kesesuaian harapan yang dapat memberikan rasa nyaman dan rasa yakin atas pelayanan yang diberikan, sehingga sesuai dengan harapan dan menciptakan rasa puas bagi pelanggan. Dalam meningkatkan kualitas layanan Family Dental Clinic harus terus memberikan layanan yang berkualitas yang nantinya akan menciptakan kepuasan pelanggan. Seperti dalam ketepatan pemberian layanan, kesesuaian representasi serta cepat dalam menanggapi keluhan pelanggan. 2). Perlu menjadi pertimbangan perusahaan melalui berbagai perbaikan berkelanjutan, terutama yang berkaitan dengan kesesuaian harga yang memberikan kontribusi rendah kepada harga dengan kata lain, harga jual harus sesuai dengan kualitas pelayanan dan manfaat yang dirasakan oleh pelanggan maka akan menciptakan rasa puas pada pelanggan.

\section{DAFTAR PUSTAKA}

Alma, Buchari. 2006. Pemasaran dan Pemasaran Jasa. Bandung: Alfabeta.

Ariani, Wahyuni. 2009. Manajemen Operasi Jasa Edisi Pertama. Yogyakarta: Graha Ilmu.

Cristo, Saerang, Worang. 2017. Pengaruh Harga, Kualitas Pelayanan, dan Lingkungan Fisik Terhadap Kepuasan Pelanggan Studi Kasus Kafe Markobar Manado. Jurnal EMBA. Vol. 5 No. 2 Juni 2017. Hal. 678 - 686.

Gerson, Richard. 2002. Mengukur Kepuasan Pelanggan. Jakarta: PPM.

Gulla, Oroh, Roring. 2015. Analisis Harga, Promosi, dan Kualitas Pelayanan Terhadap Kepuasan Konsumen Pada Hotel Manado Grace Inn. Jurnal EMBA.Vol.3. No. 1. Hal. 1313-1322.

Haryanto. 2013. Strategi Promosi, Kualitas Produk, Kualitas Layanan Terhadap Kepuasan Pelanggan Pada Restoran MC DONALD’S Manado. Jurnal EMBA. Vol.1. No. 4. Hal. 1465-1473.

Hasan, Ali. 2008. Marketing. Cetakan Pertama. Yogyakarta: Meelpress.

Hutagulung, Saerang, Tumbuan. 2015. Dampak Kualitas Servis, Strategi Promosi dan Harga Terhadap Retensi Pelanggan (Studi Kasus Pada Salon Johnny Andrean Manado Town Square). Jurnal EMBA. Vol. 15 No. 05 Tahun 2015

Kismono, Gugup. 2001. Penantar Bisnis Edisi 1 Cetakan 1. Yogyakarta : BPFE.

Kotler, Philip. 2005. Manajemen Pemasaran Edisi ke 11 Jilid 1. Jakarta: PT. Indeks.

Kotler, Philip dan G. Armstrong. 2012. Prinsip-Prinsip Pemasaran Edisi ke 12, Jilid 1. Jakarta : Erlangga.

Kotler, Philip \& Keller. 2016. Manajemen Pemasaran Edisi ke 13 Jilid 1. Jakarta: Erlangga. Lupiyoadi. 2013. Manajemen Pemasaran Jasa. Jakarta: Salemba Empat.

Madura, Jeff. 2001. Pengantar Bisnis Introduction to Business. Alih Bahasa Saroyini W. R. Salib. Jakarta: Salemba Empat.

Payne, A. 2010. Pemasaran Jasa, Pelayanan (The Essence of Service Marketing) Edisi 1. Yogyakarta : Andi Offset. 
Pujiningrum. 2015. Pengaruh Harga, Promosi, dan Pelayanan Purna Jual Terhadap Kepuasan Pelanggan di Wiratech Surabaya. Jurnal Ilmu dan Riset Manajemen. Vol.4. No. 8. Hal. 1313-1322.

Saladin, Djaslim. 2003. Intisari pemasaran dan Unsur-Unsur Pemasaran Cetakan ke Tiga. Bandung : Linda Karya.

Saleh, A Muwafik. 2010. Manajemen Pelayanan. Jakarta: Pustaka Pelajar.

Sugiyono. 2018. Metode Penelitian Bisnis (Pendekatan Kuantitatif dan Kulitatif dan R\&D). Bandung : Alfa Beta.

Sukirno, Zakaria dan Poerwanto. 2014. Komunikasi Bisnis. Yogyakarta: Pustaka Pelajar. Swastha, Basu. 2010. Manajemen Penjualan : Pelaksanaan Penjualan. Yogyakarta: BPFE. Swastha, Basu, dan Irawan. 2008. Manajemen Pemasaran Modern.Yogyakarta: Liberty Tjiptono, Fandy. 2010. Strategi Pemasaran. Edisi Ketiga. Yogyakarta : Andi Offset.

Umar, Husein. 2008. Metode Penelitian untuk Skripsi dan Tesis Bisnis. Jakarta: PT RajaGrafindo Persada.

Wiyadi. 2011. Manajemen Pemasaran Strategi dan Program. Surakarta: Smart Media. 